\title{
THE IMPORTANCE OF THE APPLICATION OF THE TRADITIONS OF "TEACHER- SHOGIRD" IN THE FORMATION OF MORAL AND MORAL QUALITIES OF STUDENTS AND STUDENTS
}

\author{
Abdurakhim Abdurakhmanovich Sultanov
}

Senior Teacher, Department Of Music Education, Gulistan State University, Uzbekistan

\section{ABSTRACT}

In the article, important tasks that should be performed in higher and secondary special educational institutions , as well as in secondary schools, in order to integrate the masterpieces of Uzbek national and classical music, as well as musical heritage of "Shashmakom" into the minds of young people, classes in the traditional style" teacher - in the process of using modern information technologies in the teaching of "traditional singing", important tasks such as providing knowledge to students and students, developing their talents and abilities, educating the younger generation in the national spirit will be resolved. The education of a harmonious person, the formation of his spiritual world, the development of his attention to national values - in fact, should begin with the primary classes of secondary schools. The awakening of love in children to all genres, spheres of art is carried out from that time. Those in the primary classes are threeraydi a lot of students with such multifaceted abilities. The solution of these issues is based on the creative activity of the master artists, on the research conducted in the process of delivering classical music performing arts to fans and the results of the experiments obtained, the experiences of their introduction into the educational process are presented and the solution of the problems that are encountered is expressed.

KEYWORDS:- Classical, status, musical heritage, performance, traditional, great singing, hofiz, artist, teachershogird.

\section{INTRODUCTION}

In the last 20 - th century, in the direction of the singer of national and classical music, many great singers left indelible tracks, immortal, lifelong songs and songs with their unique performances. These are: Haji Abdulaziz Abdurasulov, Domla Halim Ibadov, Mulla Toychi Tashmuhammedov, Sodirkhon hofiz Bobosharipov, Yunus Rajabiy, Muhiddin Kari Yagubov, Jorakhon Sultanov,
Administrjon Uzakov, Komiljon Otaniyozov and many artists of El Arda. In our classical and National Performing Arts there are traditions of teacher - shogird" from time immemorial, and this tradition continues to this day. In the formation of this IBA tradition and its application to today's youth, we must use the tradition that is inherited from it.First of all, young people who love the art of classical singing should be able to choose a good master. 
CURRENT RESEARCH JOURNAL OF PEDAGOGICS 2(6): 161-166, June

2021 DOI: https://doi.org/10.37547/pedagogics-crjp-02-06-30

ISSN 2767-3278

(C)2021 Master Journals

\section{Crossref do) 81 Google}

Accepted 25thJune, 2021 \& Published 30 th June, 2021

If we know that our ancestors from time immemorial seriously looked at the upbringing of a child, then every mother gave her child in the hands of a good teacher so that he could have a good profession. Particular attention is paid to the selection of Masters in the field of singing and singing. First of all, in order to get an education from a good musician or singer master, shogird's ability in this field should have a pleasant voice, as well as performing skills, infected with the help of his creation. To be able to choose and distinguish a good teacher, the shogird and his parents are asked to have some information about the teacher, about his skills. The following information can be read from the book "Navobakhsh tones" by Professor of Fergana State University, people's artist of Uzbekistan Sultanali Mannopov. "At the beginning of the 20 th century, the famous artist from the city of Khujand, Sodirkhon Hofiz Bobosharipov, reached. At that time, there were such Hafiz as Zahirkhan hofiz, Suleyman hofiz, Ta'rahuja hofiz, Salahan hofiz, Karimjan hofiz, parents Mirsolih, Mirabdulla and Mirfayaq. Young Sodirkhon grew up enjoying such an art atmosphere. From the sharpness of the mind, he quickly memorized gazelles and admired his Masters with his ability to master the ways of singing very quickly. As a result, Sodirkhon grew up as a famous Hafiz at the age of twenty."

In this regard, it is possible to cite an example of an IBA event with the people's memory of Uzbekistan Zhurakhon Sultanov, who shogird about the fact that the teacher artist Sodirkhon hofiz is a continuation of the "teacher - shogird" traditions. "Famous Hafiz, people's artist of Uzbekistan Zhurakhon Sultanov was born in the city of Margilan in 1903. At the age of sixteen, the voices of Mulla's Wedding Singer Tashmuhammedov, Haji Abdulaziz Abdurasulov, Domla Halim Ibadov and Sodirkhon hofiz Babosharipov heard the recorded plates themselves and looked good. To one of them, shogird makes a vow to descend, and in the end chooses Sodirkhon hofiz Babosharipov, who will climb the train and find the master artist's House. At that time Sodirkhon Hafiz's dervish had gone to the Tsar's side. Zhurakhon Sultanov says that it came to him that he chose the master and fell into a frenzy. The teacher accepts him and understands the room in which he lives, the chores that he performs tiradi In this zayl, the Sultan of Zhurakhon is engaged in household chores and other economic affairs of the master.

In the meantime, Sadirkhon Hafiz will spend the good days of the country with his own art and perform singing and instrumental classes to further enhance his performing skills during his time of homelessness. The juror Sultan was busy with household chores and household chores. A year and a half later, when Sodirkhon hofiz was on a turn trip, the Jourakhon Sultanov turned to the teacher and said, "teacher, I have been in your house for a year and a half. Do not you teach me anything?" when they say," Shall I teach you anything or bless you?"- he says. "Pray, Master," says the cockroach Sultan. Sodirkhan hofiz will pray "be known and famous hofiz to the Climate your God has reached". From what happened, it is known that Zhurakhon Sultanov for a year and a half served in the master's House, listening to his singing exercises with a soulful ear. He studied each execution of the master and received iodine. In his place, master Sodirkhon Hafiz also heard the master singing and singing during the performance of the house chores of the Sultanov. Teacher-shogird heard one from the other and enjoyed one another's performance. For this reason, Sodirkhon Hafiz shogirdidan asked the question "Can I teach you anything or bless you? - he asked.

The use of the "teacher - shogird" system of traditions for teaching students is the best way for them to learn our status and classical songs, which is the cultism of classical and National Music. Of course, for teachers to have an 
CURRENT RESEARCH JOURNAL OF PEDAGOGICS 2(6): 161-166, June

2021 DOI: https://doi.org/10.37547/pedagogics-crjp-02-06-30

ISSN 2767-3278

(C)2021 Master Journals

\section{Crossref do) 81 Google}

Accepted 25 th June, 2021 \& Published 30 $0^{\text {th }}$ June, 2021

honorable title of tabarruk, the teacher, we are asked to have perfectly mastered our statuses, masterpieces of classical music, which are inherited from our ancestors. The teachers, who made a name among the Els, were respected, deeply mastered not only the ways of performing"Shashmakom", but also its theoretical and scientific aspects, became status connoisseurs. Because without perfect knowledge of the theoretical and scientific side of our status, it is impossible to be a musharraf to the name of the master tabarruk.

To do this, the shogirds also need to have information about the structure, sections, parts of"Shashmakom", the terms of Mushkilot, prose, Sarakhbor, Tasnif, Tarje', Gardun, Miyonokh, Avji Turk, Avji Zebopari and other names spoken in Persian and Arabic. Before teaching any singing to students, it is necessary to give full information about who created the music of this singing, the text of the singing of which belongs to the pen of the poet, who is the first performer. At the same time, it will be necessary for the student to diligently listen to the recording of the original first performer on the magnetic tape of MR 3, that is, the voice, the performance.First of all, it will be necessary for the performer to thoroughly master the timbre of the voice, the style of performance, the skills of execution. It was necessary to sing Sarahbars in the prose sections of the status and the range(range) of 1 2 groups in the branches as a collective, that is, as an ensemble, in the performance of musical works, songs with one and a half to two octaves. From time immemorial, a wide range of status songs and classical songs created in the last 20 th century were also not mentioned by one hofiz. Because, as the status sarakhbars consist of income, miyonokhet, outbreak,large outbreak, these songs are said to be a community. Both previously and now rarely encountered Hafiz, whose voices worked in quality in one and a half to two octaves. Therefore, it was a tradition to sing a wide range of status songs as a team. Shashmakomni learn from a master who is a connoisseur, without adding excessive embellishment, avoidance, groans to the singing of shogird - status, as the teacher said, will breathe properly and perform on the right track.

Classical singing in our performing arts there is a style of singing, which is called cockroach, cohabitation. The singing performance in this style has been going on since ancient times. Being a cock, singing means playing one song in one breath, in the same style of performance, on the same track (there can be more than two singers, and more). The sound timbre of the Bunda Cocks is necessarily a condition that one complements the other, one corresponds to the sound of the other(falls). Shashamakam is of course also in collective execution from the periods when the Khans were originally executed in the palaces. This style of performance ensured that the status songs were sung in the same manner of performance, in the same way of performance.

From history it is known that our ancestors of the teacher artists also resorted to more cockfighting in the performance of singing. The duration of the teacher - shogird traditions is clearly manifested in this style of execution.The folk memorabilia of Uzbekistan, the chorakhon Sultanov, who laid the foundation stone of the Uzbek national singing art, and the songs sung by the Administrjon Uzakov as a rooster have been pleasing the hearts of the fans to this day. Administrjon Uzakov was one of the Masters of Art who, in the sky of the world of traditional singing, flashed and grew up like a thunderstorm. His family was also one of the family who was keen on art. Due to this should have been Administrjon had increased affection to the song from an early age. He had recognized Yusuf as an interesting, cocky Sultan, Hasan Kari, Godbergan Hafiz as his uztüzler. His teachers, in turn, put their kindness to the administrator, taught him 
CURRENT RESEARCH JOURNAL OF PEDAGOGICS 2(6): 161-166, June

2021 DOI: https://doi.org/10.37547/pedagogics-crjp-02-06-30

ISSN 2767-3278

(C)2021 Master Journals

\section{Crossref do) 81 Google}

Accepted 25th June, 2021 \& Published 30 $0^{\text {th }}$ June, 2021

to play Khasan Kari dutor, singing the godmother hofiz. The next 30 years of life and creative activity of hofiz were connected with the great artist Zhurakhon Sultanov. In particular, it would not be an exaggeration to say that the fact that he came to Tashkent and began to live here together with Zhurakhan Sultanov in 1932 was a big turn to the creativity of Administrjon Uzakov.

The songs sung by djurakhon Sultanov and Administrjon Uzakov, who spoke as a rooster, were written in gilded letters to the history of the art of classical singing. They participated in the construction of a large Fergana canal, which in 1939 became a people's insect, and earned a reputation among our people with their art. At that time, Administrjon Uzakov was awarded the title of people's memory. Administrjon Uzakov not only sang, but also became the guarantor of the fact that he played many leading roles in the music and drama theater named after Mukimi. His mentor, along with his co-founder, Gorakhon Sultanov, created a number of songs during the years of the war, including songs "I ride a horse", "Mubtaloman naylayin", "the gift of the Children of Van to the front", which was reflected through elephants.

Performing schools of Brothers Shakosim, Shoolim and Shoakbar Shojalilov, brothers Babokhon and Akmalkhon Sofikhanov, teacher artists Orifkhon Hotamov and Hakimjon Fayziyev, Kamoliddin Rahimov and Turdali Saydaliyev, brothers Ismoiljon and Israiljon Vahobov are a lesson for all our young people who have chosen the path of traditional singer performance.Today, many singers in the technique of performing cock-singing are effectively creating. In the Valley, this style is also called" solidarity". The performances of Ferghana brothers Yahyojon and Muhsinjon Muminov, Khorezm brothers Gufur and Gulom Eshchonov, hopeful young singers Furkat Ashuraliyev and Elmurod Ahmedov can be called worthy followers of the classical singing in the style of the performance of the Rooster, admiring the fans of our singer.

In Fergana Valley developed a style of traditional singing performance in great singing. Teacher artists Mamatbuva Sattorov, Madali Hofiz, Hamroqul Kari Turaqulov, Erka Kari Karimov, Jorakhon Sultanov, Administrjon Uzakov made a name in this style of performance in Uzbek classical singing art. This style of classical singing also continues from time immemorial in a form based on the traditions of "teacher shogird".From the book "Navobakhsh tones" by Professor of Fergana State University, people's artist of Uzbekistan Sultanali Mannopov, we bring the following information.

"Fergana is a popular way of performing a large song with a specific School of execution in Tashkent and is performed in Fergana Valley, Tashkent,Chymkent region of Qozog'istan. Great singing is sung by two, three sometimes four hofiz. The grand piano is characterized by the names" Likobi singing"," Patnisaki singing", and is distinguished by a distinctive style and complex melody structure. Xech what a musical instrument with a large singing will not roll, there will be a small tray or saucer in the hand of the performer. The tray emits the sound to a certain extent loud, the sound is directed to one sidetirib, without losing the method, serves to click. The Voice of the great singer is loud, the breath must be wide. Therefore, this song is performed by more classical memorabilia. The voices of the collaborators must necessarily coincide.

In the performance of the big song, the words are divided and played, depending on the number of memorabilia. If the performer is two, the first hofiz will perform the beginning of the song. When it stops, continue to the second hofiztiradi. The middle culmination of ashula(miyonokhet) again falls on the first hofiz check. Let's say together. Then the culmination part of the upper 
CURRENT RESEARCH JOURNAL OF PEDAGOGICS 2(6): 161-166, June

2021 DOI: https://doi.org/10.37547/pedagogics-crjp-02-06-30

ISSN 2767-3278

(C)2021 Master Journals

\section{Crossref do) 81 Google}

Accepted 25th June, 2021 \& Published 30 $0^{\text {th }}$ June, 2021

curtains are executed split. When unloading, a joint performance is performed. The same rules of execution are observed even if the memory consists of three or four people. For proof of these words, I would like to retreat and tell a story in which kamina(Sultan Mannopov)was a witness.

It was the autumn months of 1963 - th year. At the wedding in the city of Margilan, the teacher Zhurakhon Sultanov was accompanied by his old friend, the teacher of Khorezm artists avvali Hojikhon Boltayev. The wedding was opened by a cocky master, who gave the first place to the guests. Then the artists who came to the wedding were given one by one singing sequence. When Bazm Rose climbed to the climax, one of the push-ups asked the juror brother to tell him "Patnisaki wild quarter". Looking at the famous hofiz Mamatbuva Sattorov, who at that time condemned 80 years old, - can we say Mamatbuva brother "Patnisaki wild cattle"? that appealed. "Of course we will say that only two more people are needed," said the teacher. The cockerel brother looked and looked at the hofiz sitting. From the environment, the hofizs raised their hands as if they were students and heard the voice of "I say, Master". Although the master of the pitcher overlooked the Hafiz, Hojimurod, wherever they are in theory, the output will say together - they said.

These two Hafiz, whose voices were very harmonious, stood out from their places. As soon as they learned the master of the pitcher, the execution of the four hofiz began "Patnisaki wild quarter", which is said to belong to the Mevlana Treasury Gazali "come to a dilkuşo sucked Kelo slice". Those performances, here's the performance. The sitting push-ups were sitting without a tick, and the voice "oh" was heard in the voice of God. The singer performed her income, miyonkhati, returning to each other without a monand. When the singing reached the climax, the Hafiz increased his climax to
Mamatbuva teacher with his cockerel brother, following a great way of singing. The teachers told each row of the outbreak, and when the four hofiz sang together in their unloading, those who sat on the pavement were sent to the subconscious "uvv" -. At the end of the performance, the push-ups were long applauded.

Then Hozhikhan, who was sitting in excitement, stood up and described how high the performance of the "Patnisaki wild cattle" was, thanks to the Hafiz, describing how high it was.Such a high performance, which is rare, so far resonates under my ears. Later, under the leadership of teacher Mamasiddig Madaliyev, hafizlar Ibrahimjon Ishakov, Musajon Oripov, Qiljon Yusupov, Nazirjon Nazarov sang together, "Patnisaki wild quarter" was also performed successfully".

\section{Conclusion}

In the art of Uzbek singing, the performers of many memorabilia, status and classical songs, the singers having their own pleasant voice, tone and directions are gaining the love of our artloving people. Having lived and worked in the last century, the owners of magical voices, taking a deep place in the hearts of our art - loving people, beloved Hafiz-singers Lutfikhanim Sarimsakova, Tamarakhonim, Halima Nasirova, Saodat Qobulova, Jorakhon Sultanov, Administrjon Uzakov, Murodjon Ahmedov, Komiljon Otaniyozov, Tavakal Kadyrov, Faragat Rahmatova, Fahriddin Umarov, Mehri Abdullayeva, Rasul Kari Mamadaliyev, Habiba Oxunova, fohohkhon mamadaliyev, Zaynab polvonova, orifkhoji alimahsumov, orifkhon Khotamov and others...

This list can be continued for a very long time. These artists made a huge contribution to the art of Uzbek national and classical music and singing. 
CURRENT RESEARCH JOURNAL OF PEDAGOGICS 2(6): 161-166, June

2021 DOI: https://doi.org/10.37547/pedagogics-crjp-02-06-30

ISSN 2767-3278

(C)2021 Master Journals

crossref do) 801 Google

Accepted 25 th June, 2021 \& Published 30 $0^{\text {th }}$ June, 2021

\section{REFERENCES}

1. Rahmatova M.O., Tosheva D. Theory and methods of musical educational of children // Вестник науки и образования. № 21 (97), 2020, часть 2, С. 52-53.

2. Rakhmatov N.E. Problems of Creative Approach in The Pedagogical Activity of Future Music Teachers // The American Journal of Social Science and Education Innovations, 2 (09), 2020, pp. 855-963.

3. Ramazonova U.H., Sayfullaeva O. Makom art is a priority in the musical culture of Uzbekistan / Проблемы педагогика. № 2 (47), 2020, C. 87-88.

4. Yarashev J. Artistic and Aesthetic Features of "Buchor" Tune // Eastern European Scientific Journal. 2019, pp. 118-122.

5. Rajabov A. The development of music and instrumental performance in Central Asia // International Journal of Applied Research. 6 (5), 2020, pp. 95-97. 